\title{
The Sound of Technique: Gesture, rhythm and form in bobbin lacing in the Brazilian Northeast
}

\author{
Júlia Dias Escobar Brussi ${ }^{1}$ \\ 1 Universidade Federal do Oeste do Pará, Instituto de Ciências da Sociedade, \\ Programa de Antropologia e Arqueologia, Santarém/PA, Brasil
}

\begin{abstract}
Knocking the bobbins is how lace-makers refer to "lacing". It is an act that, at first sight, does not present any specific technical function, but which, on closer inspection, reveals itself as a fundamental elementary act for elaborating a good lace, since it ensures the firmness of the weave. Through an analysis of the different meanings of this category, the article discusses the relationship between, on the one hand, gesture and rhythm, and, on the other, effects and resulting forms. Each of the senses of knocking the bobbins analysed here are, in turn, tied to different levels of action, since all involve gestures, rhythms, effects and specific forms.
\end{abstract}

Key words: gesture; elementary acts; rhythm; form. 


\section{O Som da Técnica: \\ Gestos, ritmos e formas na \\ renda de bilro do Nordeste brasileiro}

\section{Resumo}

O bater dos bilros, modo como as rendeiras se referem a "fazer renda", envolve uma ação que à primeira vista não apresenta nenhuma função técnica específica, acaba por revelar-se um gesto elementar fundamental para a elaboração de uma boa renda, uma vez que é ele que garante a firmeza da trama. A partir da análise dos diferentes sentidos dessa categoria o artigo visa discutir a relação entre gesto e ritmo, por um lado, e efeitos e formas resultantes, por outro. Cada um dos sentidos do bater bilros analisados vincula-se, por sua vez, a diferentes níveis de ação, sendo que cada qual envolve gestos, ritmos, efeitos e formas específicas.

Palavras-chave: gestos; ações elementares; ritmo; forma. 


\title{
The Sound of Technique: Gesture, rhythm and form in bobbin lacing in the Brazilian Northeast
}

\author{
Júlia Dias Escobar Brussi
}

\section{Knocking bobbins}

Walking down the streets of the district of Canaan, we hear a sound typical of lacing, produced when the bobbins knock against one another. The area is home to the largest concentration of lace-makers in the municipality of Trairi, itself known, by state law $^{1}$, as the "land of bobbin-lacing", situated in the Brazilian state of Ceará. The law ${ }^{2}$ is justified by research carried out in the 199os, which registered at least one female lace-maker in $90 \%$ of the houses in Trairi that were visited by the researchers. The activity is hence part of the daily life of the municipality, and lace-makers use any spare time away from domestic chores to knock their bobbins. Knocking bobbins is a common expression for 'lacing', and, unsurprisingly, it was one of the first categories that I learned in the field (Brussi 2015).

The importance of the bobbins in lace-making is evident both in its role in naming the technique, and in the centrality of the tool to the process. The bobbins are cylindrical spindles made of wood, the length of which varies between 10 and 15 centimetres. A spherical head is fixed to one of the extremities, by means of which the bobbin is handled. On the other extreme, the cotton threads that make up the lace are attached, so that they are twisted and interlaced in synch with the movements of the bobbins. The bobbins thus function as extensions of the threads.

Along with the bobbins, the lace pillow, the moulds and the pins are the main instruments involved in bobbin lacing, sometimes also called "pillow lace" (Fleury 2002). The pillow has a cylindrical shape, and can be of various lengths and diameters, depending on the lacework being produced, personal preference, and the lace-maker's skill 3 . Made of thick cotton cloth, it is stuffed with dry banana tree straw to make it dense. The pillow is always a support upon which the lace is settled, or fixed. This base must be firm, and also capable of being perforated, since the mould, the bobbins (and, consequently, the threads) and the lace will be fixed to it with pins, which are similar to needles, and which come from local cactus varieties, such as the mandacaru and the cardeiro.

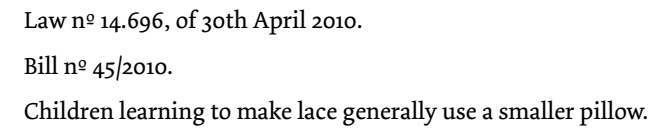


Photo 1: Pillow settled with the instruments used for lace-making: mould, bobbins and pins.

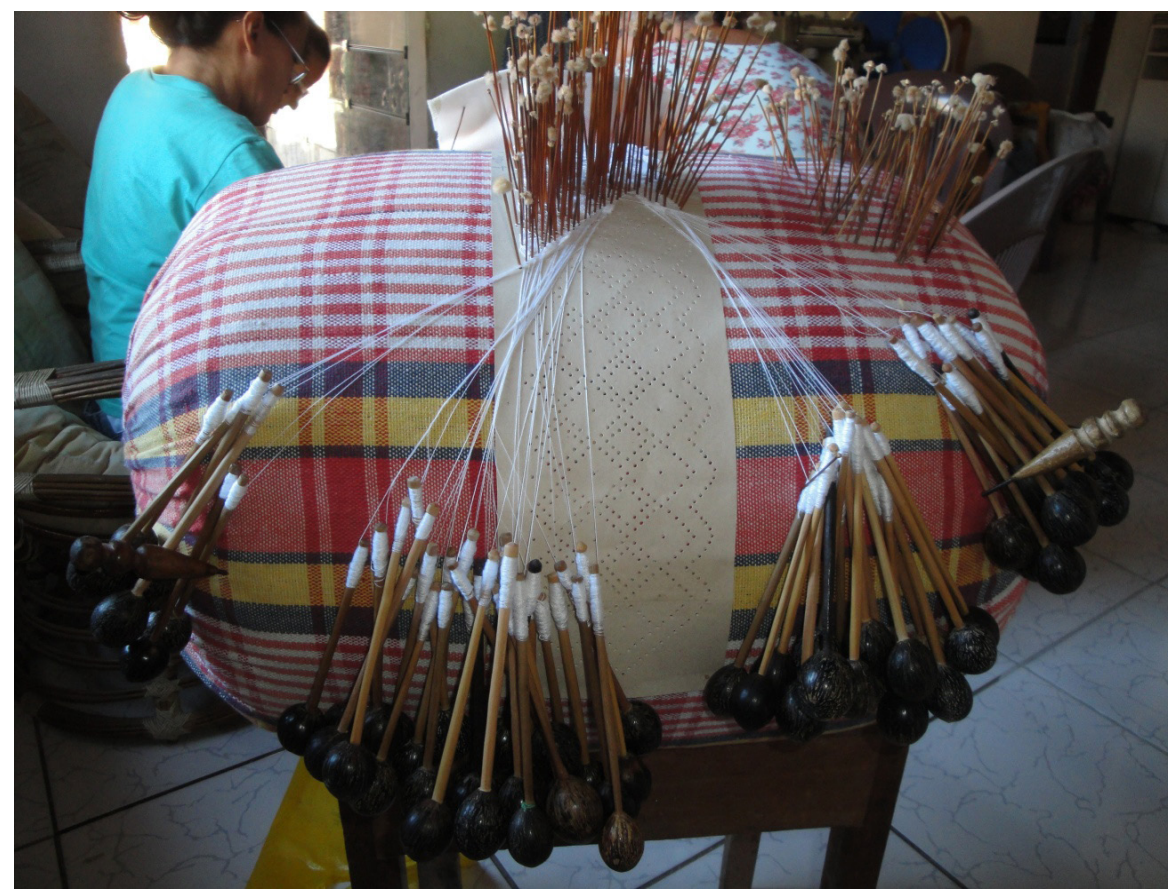

The mould is the first thing to be attached to the pillow, establishing the weave and the necessary perforations for making a specific lace. The bobbins needed to complete the lacework (always in pairs) are attached to the mould in accordance with its patterns. The number of bobbins depend on the pattern and the width of the lace. The wider and more complex the lace, the greater the number of bobbins required. Once settled on the pillow, the bobbins can be handled and interlaced according to the stitch. As the weave takes form, the stitches are attached by the pins, which will keep the threads together while the lace is confected, preventing it from coming undone. The bobbins are handled in a pendular manner, and as each stitch is implemented and the lace grows, all pairs of bobbins pass through the hands of the lace-makers.

When they are handled by the lace-makers, the bobbins' heads successively knock against each other, producing a rhythmic cadence. The sound created by knocking the bobbins is characteristic of this type of lace-making; it is the sound we hear as we walk along the streets of the village. The bobbins which the Canaan lace-makers prefer have a coconut shell tip; more specifically, it is a tucum seed, a palm that is native to the region. The preference is explained by the lightness of these bobbins when compared to those made wholly out of wood, and also for the sound they make when they are knocked one against the other, which is considered to be pretty and pleasant to the ears.

My initial understanding of the expression knocking the bobbins thus referred to the manufacture of the lace, which involved handling the bobbins and, consequently, emitting their characteristic 'knock'. As I became more familiar with the lace-makers and lacemaking, I was able to widen my understanding and comprehend further meanings of the expression related both to the importance of knocking in complementing family income and the entertainment it provides, and to the technical aspects of this operation in relation to the rhythm of production and its effectiveness, in light of how the lace is constituted.

This article focuses, precisely, on the technical aspects of this gesture which, as we will see, is central to lace-making. Through an analysis of the different meanings of this category, I will discuss the relation between, on the one hand, gesture and rhythm and, on the other, effects and resulting forms. 
We will see that each of the meanings of knocking the bobbins is linked to different levels of action, each of which involves specific gestures, rhythms, effects and forms. To this end, we will start from the classification of cloth and the emphasis on the analysis of gestures proposed by Leroi-Gourhan (1984), Mauss' concept of 'technique' and its related conception of efficacy (2003), and the hierarchy of actions established by Roux and Bril (2002).

Before we move to the various aspects related to knocking the bobbins, and in order to understand more clearly its technical importance, I will present the reader a brief synthesis of the meanings of knocking the bobbins and of lace itself, its medium and main stages of production.

\section{The many dimensions of knocking bobbins}

Canaan is an eminently rural district with fifteen thousand inhabitants. Most of the population is involved in family production, in toil in the gardens, aimed at the subsistence of the domestic group. The staple crops are manioc, maize and beans. Jobs are scarce, there are few commercial establishments and most of them are family businesses. The large properties that exist in the district are coconut monocultures and require few employees. There are few mid-range landowners that invest in the cultivation of gardens, producing sugar cane candies, manioc flour and raising animals. These landowners provide seasonal employment, mostly during planting and harvesting. During these times, workers are hired daily. Women's work is required mostly during harvesting and processing of manioc, when women are hired, also on daily rates, to make manioc flour.

In this context, income stems from lacing, a specialized job which is taken on by most women of the district. Unlike other places in Ceará (Brussi 2009), this activity is still carried out by most of the women of Canaan and transmitted across generations, from mother to daughter. Considering scarce employment, the money made from lacing is an extremely important complement, or aid, to the family budget. According to lace-makers, the positive aspect of lacing stems from the fact that it is a domestic occupation. Women can stay at home, close to their children and family, and they can divide their time between domestic chores and working on the pillow. Lacing, as a productive activity, is incorporated to the domestic routine. Whenever they are not occupied with household demands, lace-makers dedicate their time to knocking the bobbins.

The need for a constant production is in some cases justified by the requirement to hurriedly finish a lace for sale. There is, however, another factor that leads lace-makers to use up almost all of their free time with lace-making, depending on their physical limitations. This is a moral imperative that values work, as a productive use of time, and rejects idleness. Extolling work is part of the local ethos. This is evidenced by the fact that even those lace-makers that do not need the financial gain that comes with the activity, because they have other sources of income, remain committed to their pillows. After a two-month hiatus from lacing due to pain and difficulty moving, Mazé (77 years old) complained of being inactive and justified resuming her lacing, even if only for a short amount of time every day, by saying: It's very bad. I don't like to be still, a car that isn't moving carries no load. Now I do a small piece today, another tomorrow, and in time my dress is ready. In conclusion, however, she stressed: I'm not working because I'm needing it, I'm working for fun.

Mazés reasoning reveals another important dimension of knocking the bobbins for the lace-makers of Canaan: leisure. The activity is sometimes entertaining, a hobby, as one of them exclaims: it's entertaining, distracting, when you notice time has flown by. It is worth noting that, in what concerns the production of these lace-makers, the opposition between work and leisure is not all that relevant. Both are contained in the moral principle that values a productive perspective of time, which is not limited to its economic sense, but also concerns occupying the whole body. It is a way of keeping active. The continuous engagement that lacing demands occupies the time of the lace-makers while the activity is being carried out. The opportunity to focus on production is said to be an important aspect of the practice. Some lace-makers consider it a therapeutic activity: 
lace-making is therapy. As well as taking up time in an active and productive manner, knocking the bobbins also occupies the head. Away from the pillow, the head turns to daily concerns and anguishes. Mazé argues that stopping is worse, because then I just think, the lace entertains me, occupies my head and I don't think of the problems.

Thus, although prolonged lacing activity can have negative consequences for eyesight, back and legs, it also has its benefits. In general, lacing is understood to be a means to avoid idleness, to ward off thought of things that are no good, and even to prevent disease. In this vein, a lace-maker concerned with her health, who was considering a possible surgical intervention, stressed the importance of remaining active on the pillow: If I stop [lacing], I think, and I get more sick!

Lacing thus occupies a central place in the lives of those who practice it. Some lace-makers even say that they are addicted to the activity. Nenê (7o years old) revealed to me: I'm addicted, the pillow is my place, what I really enjoy and I don't see the time go by. Something we inherit from our mothers. I'll make anything from lace, so long as I'm knocking my bobbins everything is good! Remaining active is what is most important to her, as a way to productively take up her time, her head and body. We can hence understand how difficult it is for some elderly women to have to abandon the activity due to physical restrictions. One of them compared her relation to the pillow to a love affair. When we need to be far from each other we suffer, time stands still, the head is not busy.

Since it is an activity that requires constant engagement and focus, time is experienced differently whenever lace-makers are entertained with the pillow. The pace of work, carried out rhythmically and marked by the music of the bobbins, absorbs the attention of the lace-makers in such a way that they do not see time go by except through the growth of the lace and the incidence of sunlight. This recalls the relation between rhythm and concentration highlighted by Sennett (2009). In contrast to Adam Smith's description of industrial work, which establishes a relation between (an almost mechanical) routine and tedium, the author explores the state of attention and anticipation linked to craftwork which might also be described as repetitive and tedious. In his view, "rhythm has two components: the accent of a beat and pace, the speed of an action" (Sennett 2009: 197). When these two aspects converge in practice, the craftsperson can remain alert for many hours. In this way, concentration completely absorbs one in the activity being carried out.

This sense of lacking a notion of time while being entertained with lacework is reported by a great many lace-makers. The requisite engagement for lacework involves focus and concentration, which makes hours go by without the craftswomen being aware of it. I often heard stories of women who start knocking their bobbins while preparing lunch, and only remember the pan in the cooking fire when they sense the odour of burnt food.

The category analysed here has multiple dimensions, but we will present only those that are directly linked to the idea of "lacework". Before turning to the technical aspects of the activity, I will describe the lace itself and how its productive process is put into effect.

\section{Classifying lace through gestures}

Knocking the bobbins is a consequence of a movement that is at the origin of lacing. As we will see, the bobbins, and consequently the threads attached to them, can be interlaced in different ways. Hence what is called a "stitch" is a specific sequence of actions that involves four bobbins that lace-makers handle. There are many possibilities and patterns that can result. In her thesis on Slovakian lace-makers, Nicollette Makovicky (2006), questions traditional definitions of lace as textile "without a loom", thus similar to knitting, crochet or macramé. The author argues that bobbin lacing, like textiles produced on looms, is based on a combination of the threads that produces the "web" (or the warp) and the "weft". ${ }^{5}$ Thus, she argues, bobbin lace "is made by an act of weaving” (Makovicky, 2006: 77). Indeed, in some aspects, lace displays some similarities to the act of 
weaving, when considering how the threads are organized and how tensions are maintained throughout the process of managing textiles in a loom. However, when we turn to lace-making in Canaan, this similarity has its limitations, as we will see shortly.

The work of Leroi-Gourhan $(1984 ; 1985)$, published in two volumes, concerned with classifying techniques through an analysis, or taxonomy, of gestures, is extremely relevant to a consideration of technical activities. Although he does not explicitly deal with bobbin lacing, the author offers us a wealth of material on the different ways of bringing together threads and fibres, which can shed light on the present discussion. Like Ingold (2002) and Makovicky (2006) after him, the French anthropologist of techniques approximated textile weaving to basket weaving. Leroi-Gourhan's classification considers only the material, "insofar as it implies special means of treatment" (1984: 197). He thus abandons the main criteria that had been used to distinguish among and classify these techniques: form, use and aspect. The author acknowledged that while a strip of bamboo or straw can be worked on with a support, cotton threads need to be (at least partially) stretched out, and that the resulting tension, the suspension of the threads, is the main difference between lacework and basket weaving. However, considering the prevalence he attributes to gestures over instruments, Leroi-Gourhan argues that, while important, this distinction is secondary:

The fundamental fact is interweaving the textile elements, the utensils are merely a means: by their rigidity, thick fibres do not need frames, and their calibre does not require devices to move them; thin threads, in contrast, require a frame to stretch them and devices to move the numerous elements of a weft (1984: 199).

Lúcia van Velthem's (1998) ethnography of basketry among the Wayana Amerindians of northern Amazonia offers a similar perspective, privileging gestures over finished products. She draws attention to the idiom of "technical procedure" (tikaphé) used in confectioning baskets, but which also applies to pottery and weaving. The relation that the Wayana establish between these techniques is tied to the gestures that their production requires, as the Wayana conceive them: "This designation [tikaphé] indicates that this technical procedure requires work with both hands, in similar movements, and not that the Wayana consider making baskets to be the same as making pots or anklets" (van Velthem 1998: 20).

Returning to Leroi-Gourhan's classification, the first element considered is how the threads are crossed, whether in textiles or baskets. The disposition of fibres in crossed layers (horizontal-vertical or diagonal) can occur successively or simultaneously. In the first case, characteristic of weaving textiles, the weaver starts with a vertical disposition of a layer of threads (the warp), before threading the second layer (the weft) perpendicularly over the fixed layer. When the two tasks ate performed simultaneously, both layers are crossed over the same base, diagonally, resulting in braided patterns. These modalities of interlacing layers result, respectively, in a direct weave (horizontal and vertical layers) and a diagonal weave.

The second element of his classification derives from the first, and concerns the fundamental characteristics of interweaving by means of which the moveable elements (the weft) can be crossed through the fixed element (the warp). Leroi-Gourhan lists three possible ways of crossing threads, which may be spiralled, chorded, and woven. The third and final characteristic observed by the author is the fixed number of elements that are crossed, above and below, by the moveable elements of the second layer.

Leroi-Gourhan's classification allows us to develop Makovicky's (2006) comparison of Slovakian bobbin lacing and weaving. This approximation, based on the presence of the bobbins, the pillow and pins, is coherent, since it creates, respectively, a supporting base, fixation and a weight that keeps the threads in tension. Analogously, the loom also produces a support that keeps the threads stretched. However, when we consider the sequence in which the threads are crossed, and the ways they are crossed, this approximation becomes less plausible. Although Makovicky (2006) accepts the possibility of producing, on the pillow, different laces from those produced on the loom, she persists with the comparison, because, in her point of view, the bobbins being 
handled are always divided between the pair that composes the "warp" and that which produces the "weft". If, however, we consider the first aspect of Leroi-Gourhan's (1984) classification, related to the position of the layers and the sequence of their production, lace-work and weaving occupy opposite positions.

While lace-work is produced simultaneously, loom-weaving is always produced sequentially - that is, first the fixed layer, or warp, is set, so that then the weft can be built. This means that in bobbin lacing we do not find two layers that cross each other successively. All threads are attached to the pillow and hang vertically, being interlaced simultaneously. Furthermore, each stitch of the lace presents a peculiarity in terms of how the threads are crossed, which can occur both in a vertical-horizontal direction as well as diagonally. From the point of view of Leroi-Gourhan's (1984) classification, therefore, bobbin lace presents characteristics that can be seen to be incompatible, since it includes, at the same time, patterns that are defined as proper to simultaneous or successive processes and, even, a pattern which is mentioned as being proper to basketry, and which would be inexistent in weaving.

Although lace is not present in Leroi-Gourhan's (1984) classification, his description is relevant to the present case since it highlights the ways of interweaving threads in relation to the gestures that give rise to them. Every one of the stitches of the lace is constituted by a way of crossing the lines. As we will see, the final form assumed by each crossing is, like the lace as a whole, related to the gestures and sequences of the movement that produced it. This is why it is important to consider textiles by the gestures that create them, rather than by the final form that they assume.

Considering our aim, which is to understand the importance and consequences of knocking the bobbins for the production of lacework, and adding to this Leroi-Gourhan's claim that 'the utensil only really exists in the gesture that makes it effective" (1987:33), the author's view on gestures emerges as central. It is thus essential that we turn to how the bobbins are put into action and how we build a path from gesture to lace.

\section{From gestures to lace: delineating an chaîne operatoire}

In his description of technical, facts, Sigaut argues that techniques are not something we see; what we see is only people "doing things" (2003a: 424). We have access to a series of actions and the respective transformations that they cause, the marks of which are visible, since they leave traces in the materials used. The first step in the study of technique is, therefore, the materialization of that which is being made, so that we can analyse it. The tool which makes this transition possible and which enables the actions, elements and transformations involved in a technical activity to be captured, is the chaine operatoire.

The concept of the chaine operatoire, and the different forms of constructing and using it, have been presented and debated by a series of scholars, such as Leroi-Gourhan (1984), Lemonnier (1992), Schlanger (2005) and Coupaye (2009). In keeping with the aims of this article, it is enough to characterize it as a process wherein agents, tools, and materials are related toward a final project, that is, a product (Cresswell 1996: 46). It is a methodological tool, the main function of which is to try and organize the technical actions involved in production by means of an chaine operatoire. As well as making visible the sequential nature of the technical process (Schlanger 1991), it aids the ethnographer in visualizing these processes, since it makes evident a sequence of gestures and the different stages of the transformation of material (Coupaye 2009: 441).

Each sequence enables the production of a small variety of products and consists of a process composed of a certain number of stages. Each phase that makes up this series can involve specific agents, instruments, technical gestures, raw materials and results. Presenting a process in stages, however, is not mean to simplify or segment the technical activity, the actions of which, in practice, are processually enchained without any clear division into phases that follow successively one from the other (Ingold 2011: 53). 
Thus, what the chaine operatoire organizes as a linear sequence of stages, is, in fact, a complex process in which the practitioner is engaged and in which she is related to the properties and limits of the instruments and materials. In an analysis of the possibility of defining an chaine operatoire for metallurgy, Ingold (2013a: 26) sums up his argument:

Instead of the concatenation of discrete operations to which analyst of techniques have given the name chaine operatoire, we have here something more like an unbroken, contrapuntal coupling of a gestural dance with a modulation of the material.

Ingold brings us back to the gesture, an action that is at the base of the productive process, and, therefore, of the chaine operatoire, along which they are grouped into distinct and successive stages. It is gestures, like knocking the bobbins, that integrate the lace-maker to her pillow, her bobbins, and the lace she produces. Understanding lace through its gestures, as a product that results from relations established between the lace-maker, her instruments and the environment, requires attention to the forms by which they are classified, enchained and grouped.

In an approach to technical expertise, Roux and Bril (2002) show that an action (or a sequence of actions) can be considered in three different levels. The first is the level of "elementary acts", those which, from a functional point of view, cannot be decomposed into smaller units. The next level is that of "sequences of operation", which constitute the chains of elementary acts. Finally, at the widest level, we find the "course of action", which refers to the organization of the activity as a whole and to the succession of operations coordinated towards a final aim. Although it is more restricted, this last, most encompassing level, comes close to the concept of 'chaine operatoire' which, for its part, considers and incorporates the more elementary levels identified by the authors.

Although the lace stitches are quite diverse, as we saw in Leroi-Gourhan's (1984) classificatory scheme, each one being characterized by a type of interlacing of the threads, all of them are nonetheless elaborated by the different combination of only two gestures, the 'twist' and the 'switch' (trocado). Taking Roux and Bril's (2002) distinction of "levels of action", these gestures can be described as "elementary actions". In the act of twisting, two bobbins are placed in the palm of one hand (the action usually takes place with both hands simultaneously, but this is not a requisite) and have their positions inverted. The action of switching, in turn, can be described as throwing a bobbin from one hand to the other. Knocking the bobbins is involved in both situations, since in both of them the heads of these instruments touch and make the knocking sounds that characterizes the activity. 
Figure 1: Movement of the bobbins during the twist

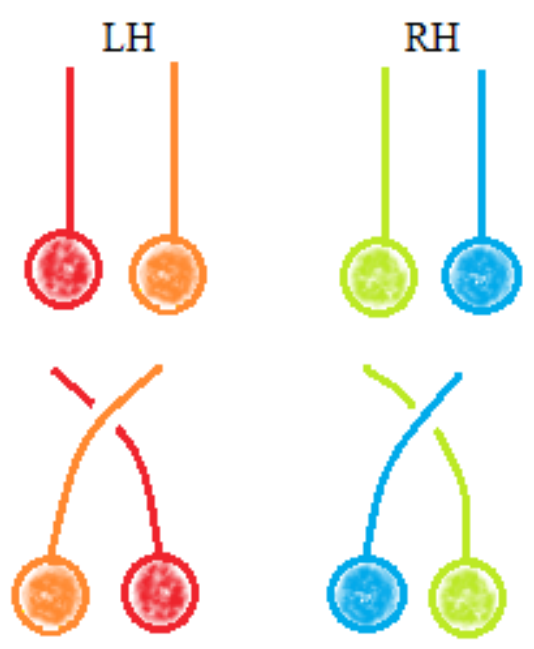

Figure 2: Movement of the bobbins during the switch

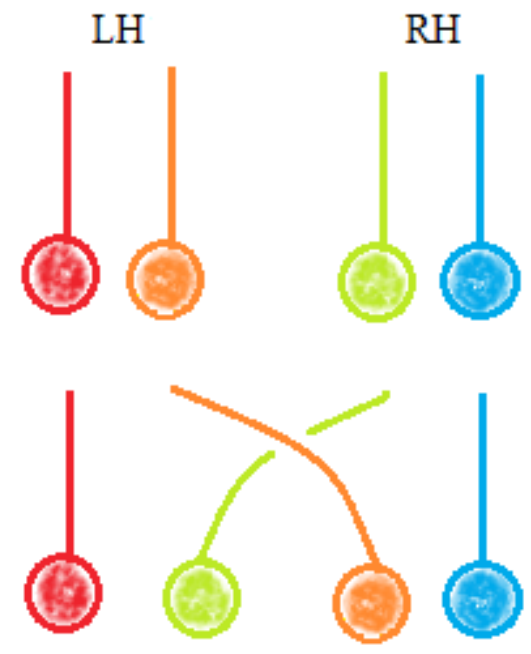

Following the hierarchy of actions, we may consider that each lace stitch is a "sequence in the operation", since it involves different sequences of the "elementary actions" described above. The "course of action", in turn, is related to filling in the frame as a whole and forming the weave. The engagement with and attention to each of these stages is reflected in the quality of the final product. However, as we will see, the elementary acts are particularly relevant toward this end.

If we take the idea of the chaine operatoire in a restricted sense, as an exact sequence of operations moving from the raw material to a final product (Creswell 1996), we can see that each mould (or each lace) has its own chaine operatoire. Certain elements of this sequence, however, remain the same, regardless of which lace is to be produced. These include the agent (lace-maker), the instruments (pillow, mould, bobbins, pins and scissors) and raw material (thread). As to the succession of acts, although they vary according to which piece is being produced, it is possible to define certain stages that are common to all lacework. These can be considered necessary stages, and will be synthesized in what follows. 
The process of producing lace is composed of five main movements, which cover the organization of the tasks, its beginning, development, conclusion and the removal of the pillow. Although these stages are obligatory, they can be executed in different ways. It is thus interesting to think of the chaine operatoire in association with the levels presented by Roux and Bril (2002), since every stage can be developed through a distinct "sequence of operations". The chaine operatoire is not, therefore, linear and planned, but involves, instead, different skill levels and choices relative to the gestures themselves, to the thread and to the use of the mould.

The preparation for starting an activity is the first phase of the process (Ingold 2011: 51). Before the lace is settled (assentada) on the pillow, a series of acts must be executed. The main task is to fill (or charge) the bobbins that will be used with the thread, or threads, that will compose the weave. Lace-makers describe this task as the most boring and monotonous aspect of lacework, both because of the time it requires and the strain it causes on the hand and arms due to the repetitive movement of rolling the line onto the spindle. Despite being tedious, this stage is very important and can influence the remainder of the activity, as highlighted in the following complaint of a lace-maker whose bobbins were charged by someone else, and who was dealing with the consequences of this while knocking her bobbins: She filled my bobbins, but I didn't like it because the thread is coming loose. It needs to be very taught, or the line flees. The fact that the lines are loosely wrapped around the bobbins causes difficulties for the lace-maker in maintaining the tension of the weft. As we will see, for some lace-makers this is a central factor in the production of lace.

Preparations for the activity also include pairing the bobbins and fixing the mould to the pillow. When this is done, all is ready for the lace to be settled on the pillow. This stage consists in fixing the pair of bobbins onto the cardboard, an essential step for initiating the lace. Depending on how they are placed, the bobbins can be interlaced, always according to the stitch (or "sequence of operation") required by the mould. The remaining pairs of bobbins will be inserted according to their need, and once all are attached to the mould and interlaced, it is said that the lace has been settled.

The succession of movements that are to be realized from this moment on is defined by the mould, which determines the sequence of stitches and their pattern. All of the mould should be traversed and filled in during the process. More experienced lace-makers are able to use the moulds in different ways. In this sense, the same mould can be executed by different combinations of "sequences of operation". The following stage is the completion of the lacework, when lace-makers join the threads of each pair in a knot, completing the weave. Threads can hence be cut and the bobbins removed. The last stage is the removal of the pins that still attach the lace to the pillow, and the release of the now finalized lace.

The table below summarizes the main acts, instruments and gestures used in each of the stages of producing lace referred to above. We here consider the agent (the lace-maker) and the raw material (the thread) to be constants, which accounts for their absence from the table. It should be mentioned, however, that lace-makers may receive help from another practitioner, such as a relative or daughter, during any stage of the process. 
Table 1: Stages of the chaine operatoire of bobbin lace

\begin{tabular}{|c|c|c|c|}
\hline Stages & Acts & Tools & Main Gestures \\
\hline \multirow{3}{*}{$\begin{array}{l}\text { 1. } \\
\text { Organization }\end{array}$} & Filling the bobbins & $\begin{array}{l}\text { Bobbins and } \\
\text { scissors }\end{array}$ & $\begin{array}{c}\text { Rotation of the bobbins } \\
\text { on their axes }\end{array}$ \\
\hline & Joining the bobbins in pairs & $\begin{array}{l}\text { Bobbins and } \\
\text { scissors }\end{array}$ & $\begin{array}{l}\text { Join the extremities of } \\
\text { the threads in a knot }\end{array}$ \\
\hline & Attaching the mould to the pillow & pins & Sticking pins \\
\hline \multirow{3}{*}{$\begin{array}{l}2 . \\
\text { Settling }\end{array}$} & Attaching the first pair to the mould & pins & Sticking pins \\
\hline & Interlacing the first pair & Bobbins and pins & Twist and switch \\
\hline & Introducing remaining pairs & Bobbins and pins & Twist and switch \\
\hline $\begin{array}{l}\text { 3. } \\
\text { Descending the lace } \\
\text { (Executing the mould) }\end{array}$ & Executing the sequence of stitches & Bobbins and pins & Twist and switch \\
\hline \multirow{2}{*}{$\begin{array}{l}\text { 4. } \\
\text { Finalization }\end{array}$} & Joining the threads of each pair & Bobbins & $\begin{array}{l}\text { Joining the extremities } \\
\text { of the threads in a knot }\end{array}$ \\
\hline & Cutting the bobbins & Scissors & Cutting with scissors \\
\hline \multirow{2}{*}{$\begin{array}{l}\text { 5. } \\
\text { Removing the lace }\end{array}$} & $\begin{array}{l}\text { Removing the pins that still hold down } \\
\text { the mould and the pillow }\end{array}$ & & Picking pins \\
\hline & Removing the finalized lace & & \\
\hline
\end{tabular}

The table establishes what can be described as the necessary stages, that is, those that are common to all types of lacework, regardless of the model being produced, the skill of the lace-maker, or her options in what pertains to the mould she will produce. In this exercise, which seeks to trace the path linking gestures to lacework, it is evident that the actions defined in this table basically correspond to first and last acts involved in the production process. Between these stages, the "elementary actions" and the "sequences of operation" vary, since they depend on the design of the mould and the lace-makers options as she makes the lace.

There are yet two sets of movements that should be highlighted and which can be carried out in any of the stages that involve use of the mould, from the moment of settling until the conclusion of lacework. The first set of acts can be defined as "occasional", since they must be executed at certain moments during production, although such moments will be difficult to envisage beforehand. This set of movements include, for example, the substitution of loaded bobbins for dry ones, that is, those that have no more threads, or the need to mend a thread that has ruptured.

The second set of acts is a specific type, for, although it is not associated to the constitution of the weft as a whole, and hence does not need to feature in a "generic" chaine operatoire such as the one I have tried to elaborate, is interesting for the present discussion because of its relevance to the lace-makers who use it. Besides that, it is also closely related to the idea of knocking the bobbins. 


\section{Knocking the bobbins as a technical gesture}

As I have said, my conception of the meaning of knocking the bobbins slowly widened, as I become more involved in the context of Canaan, became closer to the lace-makers and to lacework. It was because of this growing proximity, including my own apprenticeship in lace-making, that I began to understand a central aspect of the process: that knocking the bobbins is not only a way of referring to the production of lace itself, but also a specific technical gesture.

According to Mauss (2003: 403), technique is defined as a "traditional effective act". Considering its effectiveness, it is a way of doing, an act that fulfils a determinate aim, that produces an effect in terms of a desired goal. Up until this point we have been dealing with different aims, or effective forms, related to knocking the bobbins as an act of lace-making, such as the possibility of making some money, of entertaining oneself, of filling up time and occupying thought. However, there is another result that can be obtained from knocking the bobbins which involves understanding these acts in the terms of Leroi-Gourhan (1984), as an action on matter, or, in this case, on threads.

With a succession of observations and the intensification of my comprehension of the gestures carried out and the transformations that they cause, or the traces that they leave on the material being used, I noticed that some lace-makers would knock the pairs that had been used against each other, making their heads hit one another, after each stitch, or each "sequence of operation", was executed. The main difference between the two types of knocking is that, in the case we have discussed above, where knocking the bobbins is equivalent to lace-making, knocking is unintentional, or just a consequence of the way the bobbins are handled. In this latter case, however, the bobbins are intentionally knocked against each other, as they are pulled down. This act is similar to the twist that involves the pair of bobbins that the lace-makers have in each hand, but instead of then changing their positions they are moved so as to touch one another. In other words, while the former sense of knocking the bobbins results in the production of lace, the second has a specific result, since it increases the tension of the threads that are laid on the mould and ensures greater firmness for the weave as a whole.

Figure 3: Movement of the bobbins during the snap (estalo)

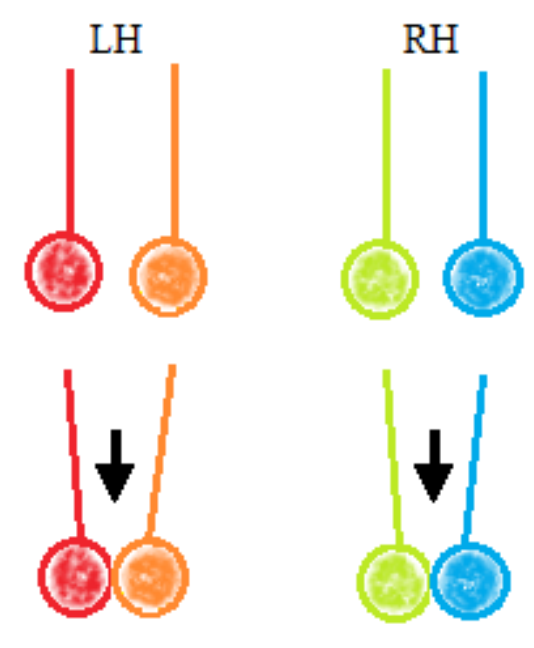

We thus have two different modalities of action, with different results - or, in the words of Mauss, distinct effects. Referring to the different levels of action delineated by Roux and Bril (2002), we may say that the former modality of knocking the bobbins comes close to the most comprehensive level, the "course of action", since it involves the whole process of lace-making, while the latter is a type of "elementary act" which cannot be decomposed into smaller units. 
Considering my attempt to establish an chaine operatoire for lace-making, we can claim that knocking the bobbins, as a technical gesture, is used in phases that involve the construction of the lace itself - that is, in the moments of settling ( $2^{\text {nd }}$ stage) and of descending the lace ( $3^{\text {rd }}$ stage). It would thus be joined to the twist and the switch, which are the main gestures of these phases. It should be noted, however, that although they represent "elementary acts" and participate in the same phases of production, or of the chaine operatoire, there is an essential distinction between these acts. While the twist and switch are fundamental to constructing the weft, the snap that emerges from knocking the bobbins does not influence its constitution, even if it has a direct impact on its aesthetic result and quality. Taking Leroi-Gourhan's (1990) distinction, the twist and the switch belong to the acts of the fixed series of the chaine operatoire, while the snap composes the flexible series. In Lemonnier's (1986) terms, in contrast, the first type of act constitute strategic operations, those that cannot be omitted without jeopardizing the whole process, while knocking the bobbins represents a technical variation, for although they are relevant in cultural and social terms, they are not obligatory.

As I have mentioned, not all lace-makers use knocking the bobbins as a technical gesture in the production of their lacework. This action may thus be present, or not, in the definition of an chaine operatoire, depending on whether it is used by the practitioner being observed. In what concerns the issue of how knocking the bobbins is to be integrated into the chaine operatoire, it is useful to refer to Coupaye's (2017) reflection on the potentials and limits of this methodological tool through his attempt to apply it to yam cultivation among the Abelam of Papua New Guinea.

In this work, Coupaye proposes that we adopt two distinct methodological positions regarding the chaine operatoire, which I will now present since it speaks to the aims of this article. The first is that we be attentive to the essentially descriptive character of the chaine operatoire, which represents an always incomplete transcription of the ethnographer's observations in the field. It is hence "no more than the capture of a unique event, observed at a specific time and place" (Coupaye 2017: 480). The second position, which is of greater interest to us, concerns the Maussian idea of technical acts as "traditional effective acts" (Mauss 2003: 403). Starting from this conception, Coupaye stresses that the ethnographer needs to take into account the "ethnoconceptions" of efficacy that play a part in technical processes. That is, we must consider what is effective from the point of view of the agents with whom we interact in the field. The chaine operatoire that the author constructs thus includes "what cultivators deem necessary for the proper development of the tasks" (Coupaye 2017: 481). In this sense, knocking the bobbins as technical gesture is considered, by some lace-makers, to be a central step for obtaining a lace that conforms to their criteria of quality. It is to these criteria that we will now turn.

\section{The effects of knocking the bobbins and the fine lace}

On a first impression, the expression knocking the bobbins had an evident sense related to lace-making. It has gradually emerged as a more complex category with multiple meanings. At first I was unable to visualize the act of knocking the bobbins as an act in itself, and tended to frame it as a habit with no practical effect. This perspective was justified to the extent that the act did not constitute an important movement for constructing the lace, which is what I was seeking to understand. The realization that this act is an important technical gesture only occurred when I came across what lace-makers consider to be a high-quality lace, or what they describe as fine lace. From this moment on, I understood that the knocks, or snaps, were neither unnecessary nor random, but rather had a central function in relation to the specific aim of producing fine lace. 


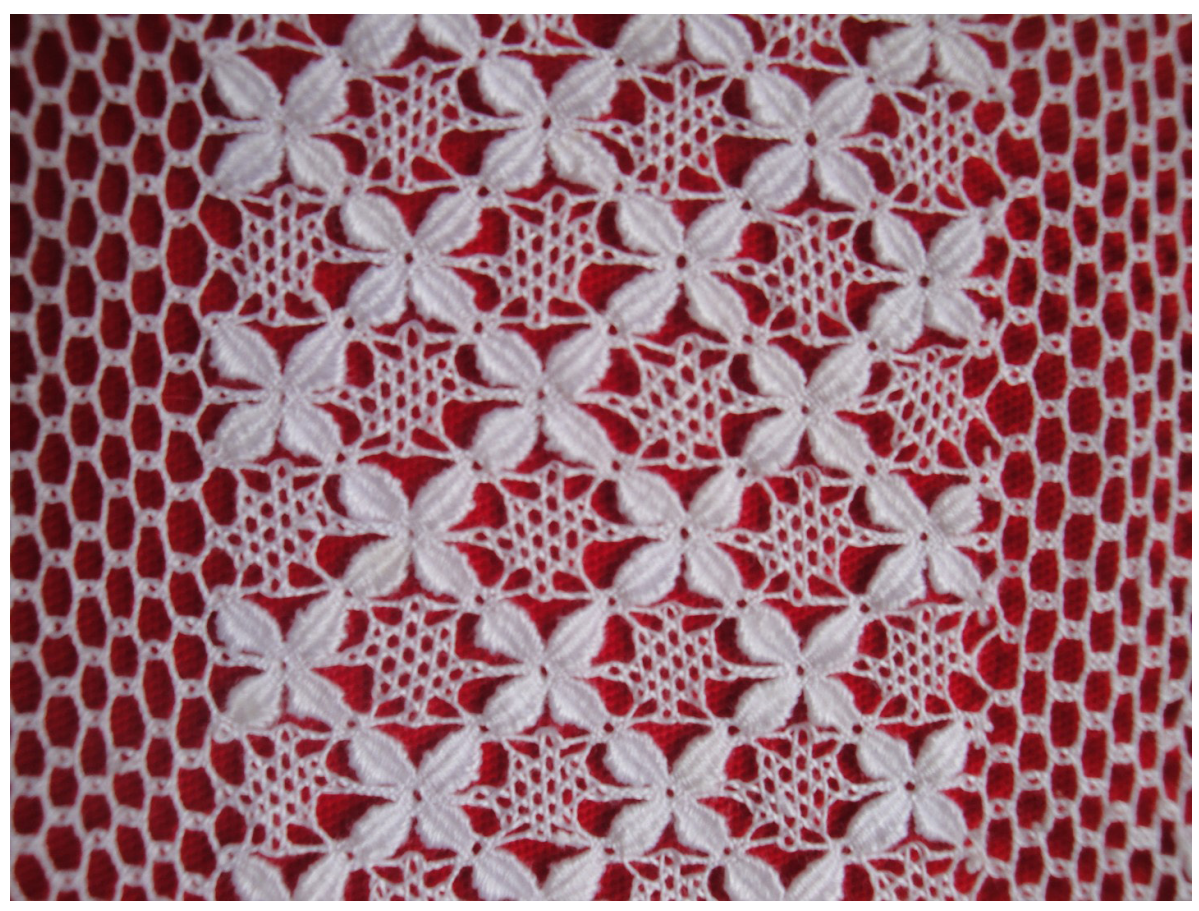

Prolonged contact with the lace-makers enabled me to access the criteria and the elements that they consider necessary for a lace to be classified as fine. This classification involves both formal aspects and technical aspects of production (Brussi 2017). It is interesting to observe that both are related. The indispensible attributes of fine lace, from the point of view of their makers, are firmness and weight, as well as cleanliness, quality finishing and a well-defined form created by the stitches. All of these criteria are intimately linked to the technical processes of making lace. It is no accident that lace-makers also call lace of this type more worked or well done lace. It is precisely because fine lace results from a more unhurried and laborious process that it can be described as fine.

The three main "elementary actions" that participate in the construction of the lace are, in this sense, essential to ensuring fine lace. All of these acts can be carried out with greater or lesser rigour. As we have seen, unlike the snap, the twist and the switch cannot be omitted from the chaine operatoire since they are necessary acts for producing the weave. Nonetheless, they can be reduced or simplified, as we will see. Considering the financial needs of the families of Canaan, lace-makers are sometimes in a hurry to finish their pieces, so that they can be sold and used to buy essential goods for household subsistence. Many therefore opt for producing less worked, hence simpler lace. As well as being made in less time, this choice also decreases expenditure in threads, an expensive raw material for most lace-makers.

An example of this simplification of the technical process involves the basic stitch of the lace, which also names one of the "elementary acts", the switch. This stitch can be executed in two ways, as a half-switch and as a full switch. The "sequence of operation" of a half-switch is composed of a twist followed by a switch, and the only difference between them is that the full switch is formed by the execution of two half-switches in sequence. In the opinion of the more careful and demanding lace-makers, there is a huge difference between lace produced with the full switch and that made with the half-switch, both in what concerns its quality and its appearance. Describing the ideal way to make lace, Alda (76 years old) said: It has to all be in the full switch, all closed up, so that it's very firm. When you remove it from the pillow, it stands straight! The fact of closing a stitch with a full switch keeps the threads closer together and the lace firmer. The opposite of well done lace is rangarela lace, which means loose, open, frayed. 
As we saw above, the twist is the first movement to the executed to make a switch stitch. The importance of this gesture, however, goes beyond its role in making this stitch, since it is the main factor ensuring a firm lace, with well-defined forms and patterns. By twisting the threads of each pair of bobbins before carrying out their switch, lace-makers guarantee that the tension is kept in the lace. Furthermore, throughout the production of the piece, careful lace-makers are always twisting the threads attached to each bobbin on its own axis. They do this because, as they handle and manipulate the bobbins, the cotton threads tend to lose their natural torsion, becoming more fragile and likely to tear. The constant twisting of the line also makes them thinner and smoother, so that they glide easily when rubbed against one another.

Finally, knocking the bobbins is an act that, while not necessary for producing the lace, is fundamental for the production of a fine one. It is this movement that ensures that threads remain uniformly distributed throughout the weave, which contributes to the symmetry of the stitches and the definition of the patterns. They also keep the threads in tension, guaranteeing that the weft remains more firm and stretched out than it would be without this act. The pins here play a central role, since they serve not only to keep the threads united through the stitches, but also help in keeping the lace tensioned, generated by the acceleration and traction of the movement of knocking the bobbins. The firmness of the lace therefore results from, and is proportional to, the investment in the snaps of the bobbins while it is being produced. Jeane (35 years old), a lace-maker who prefers to produce well done lace, despite the fact that its commercial value is no different from rangarela lace, describes the importance of knocking the bobbins: Without knocking the bobbins, the lace is soft. The more we knock the bobbins and tighten (acochar) with the snaps, the harder and more stretched the lace is. There are people who do the switches and leave it to the side, and the lace then doesn't tighten!

\section{Gestures, rhythms, effects and forms}

Returning to Mauss' (2003) concept of technique as a "traditional efficient act", I hope that it is by now clear how the elementary gestures that we have been concerned with, in particular knocking the bobbins, produce effects in the final result of the lace. In the same vein, we can refer to François Sigaut's (2003b) text "Le formule de Mauss", in which he develops Mauss' definition of technique. Focusing on efficiency, and looking to respond to some criticisms that the concept has received, the author looks to add precision to the notion's definition. In his view, an effective act is that which produces an expected effect and, more importantly, an effect which has physical, material sense. It is thus sensible, available to perception (Sigaut, 2003: 5).

There is, however, another fundamental element in bobbin lacing that relates to the gestures, and which needs to be discussed here: rhythm. As we have seen, the gestures and movements of lace-making follow a rhythm, including that of knocking the bobbins, or the successive clash between them, which create a punctuated beat. It must be stressed, therefore, that this rhythm, as a compass generated by the gestural movements of the lace-makers, also has a physical effect on the weft that is produced. If our aim is to follow Leroi-Gourhan's view on action upon matter, and to describe the weave of the lace through gestures and the set of acts that are at its origin, then rhythm assumes a central importance.

Leroi-Gourhan had already addressed this issue. As Alexandra Bidet (2007) notes, his work is shot through by an anthropology of rhythm. Through the revaluation and amplification of this concept, he turns to the empirical aspects of human existence, with a view toward the relation between corporality and sociality. The notion of rhythm permeates his analysis of the genesis of aesthetic and the social (Bidet 2007: 2). For the purposes of my analysis, I draw attention to Leroi-Gourhan's (1987:114) claim that “all making involves a dialogue between maker and matter". 
This dialogue is established within an environment that the author calls rhythmic, at once muscular, auditive and visual. Technical operations hence involve gestural repetition and regular time intervals, a temporal rhythm that is defined by gestures is translated into space. Rhythms create form (Leroi-Gourhan 1987: 117).

In his work on "Primitive Art", Franz Boas (1951) presents a similar analysis of form and the meaning of art, particularly among the people of Northwest Coast of North America. He establishes a relation between decorative forms and the rhythmic repetition of certain movements, or, as Roux and Bril (2002) would call it, "sequences of operation". In Boas' view, activities such as pottery-making and weaving connect the regularity of form to rhythmic movements involved in the production. Temporal rhythm is thus created by gestures that materialize in different types of form and pattern (Boas 1951: 40)

Considering knocking the bobbins as a polysemic concept, we can view each of its meanings, themselves implicit in distinct levels of action, through, on the one hand, the relation between gestures and rhythm, and, on the other, the physical effects and resulting forms. When knocking the bobbins simply refers to "lacemaking", the knocking of the spindles have no expected consequence, producing no discernible physical effect. It is just a way of referring to the activity as a whole, with no indication as to the quality of the lace that is being made. In contrast, when knocking the bobbins is considered an elementary act, it seeks a result, or a specific effect, related to the tighter tension of the lace. In this case, the lace-maker must execute more gestures, which requires more time, but results in a fine lace. If this elementary act is omitted, the rhythm of lace-making is accelerated and the amount of gestures that need to be executed decrease, resulting in an inferior, tatty lace - a floppy lace. These relations are synthesized in the table below. Its aim is to schematize these connections and to make evident the fact that knocking the bobbins has different meanings that, for their part, are linked to distinct levels of action. In practice, however, these relations are more complex, and both meanings can be combined in a single movement. This is what happens when a lace-maker opts to produce a fine lace. They associate both senses of knocking the bobbins, since they make lace and snap the bobbins after each stitch is concluded, so as to make it firmer.

Table 2: Schematization of the two meanings of knocking the bobbins and the relations established in each case

\begin{tabular}{|l|l|l|l|l|}
\hline $\begin{array}{c}\text { Knocking } \\
\text { bobbin }\end{array}$ & $\begin{array}{c}\text { Associated } \\
\text { level of action }\end{array}$ & \multicolumn{1}{|c|}{ Knocking } & $\begin{array}{c}\text { Rhythm } \\
\text { (time, cadence of work) }\end{array}$ & $\begin{array}{c}\text { Resulting forms } \\
\text { (space), or } \\
\text { physical effects }\end{array}$ \\
\hline $\begin{array}{l}\text { While lace is } \\
\text { being made } \\
\text { "course of } \\
\text { action" }\end{array}$ & $\begin{array}{l}\text { Unintentional } \\
\text { (a consequence of the act } \\
\text { which does not seek to } \\
\text { produce a specific effect) }\end{array}$ & $\begin{array}{l}\text { + acceleration / } \\
\text { - gestures to be executed / } \\
\text { shorter cadence }\end{array}$ & Floppy lace \\
\hline $\begin{array}{l}\text { As a technical } \\
\text { gesture }\end{array}$ & $\begin{array}{l}\text { Intentional (aiming for a } \\
\text { specific effect, seeking a } \\
\text { lace with greater tension) }\end{array}$ & $\begin{array}{l}\text { - acceleration / } \\
\text { + gestures to be executed / } \\
\text { longer cadence }\end{array}$ & Fine lace \\
\hline
\end{tabular}

Regarding, on the one hand, the relation between gestures and rhythm, and, on the other, the effects and forms that they generate, it is useful to recover Ingold's (2013b) reading of Leroi-Gourhan. Taking into account the view of production as a dialogue between maker and matter, Ingold suggests that this dialogue takes the form of a succession of questions and answers, where each gesture seeks a response, a reaction or, in Mauss' words, an effect from matter, which, for its part, enables the work to continue towards a desired goal. A correspondence is established, in which matter registers the actions of the maker, their regularities and imperfections (Ingold 2013b: 121). 
In a perspective that focuses on the relation between rhythmic movement and emergent form, Ingold (2013b) narrates the experience he shared with his students in trying to produce rope by hand, and the four lessons they learned in the process. The first thing they became aware of during the activity was that hands were capable of learning how to know, or "feel", the material. The other lessons concern the relations between gestures and matter. Experience and practical engagement with the material allowed them to perceive form as the rhythm of bodily movement transmitted to the material. Analogously, they noticed that the material conveyed the memory of how it was manipulated, since gestures become registered upon it. Finally, Ingold highlights that it is the forces and energies applied to the materials, by way of gestures, that keep them together. The form of lace is generated thus in the field of forces constituted by the relations between the gestures and bodily movements of the lace-makers and properties of the material they handle - threads, in this case.

The sound, or music, heard as one walks through Canaan, produced by knocking the bobbins, is not dependent on the level of action of the lace-makers, on the rhythm they impose, or the forms they create. If the knocking of the bobbins does not need to be intentional, since they are implied in the very process of bobbin lacing, the same is not true of rhythm and form. The rhythm maintained by the lace-maker, much like the aesthetic result of what she produces, is deliberate, and follows from a choice that involves factors such as skill, physical condition and financial status.

Making fine lace, which is also considered visually prettier and more harmonic, requires, we have seen, more time and greater attention and care to the "elementary actions". Well-defined contours and the symmetry of forms are directly tied to the ideal tension of the thread, and, therefore, to the purposeful snaps of the bobbins while the lace is being produced. By stressing the importance of gestures to the construction of the forms and patterns of lace, and proposing an approach that relies on them, I have sought to distance myself from analyses which are based on the relation between function and form (symbol/style), delineating a alternative framework.

Considering the relations analysed in this article, between gesture, rhythm and form, one final reflection should be made. It stems from the fact, already presented above, that each stitch of the lace is composed of a specific sequence of movements, of twists and switches of the bobbins. As in the chaine operatoire, in which each act is to be analysed in relation to the total sequence, the role of rhythm can likewise not be understood by focusing on each knock on its own, segmented from the rest, but rather through the gestural set as a whole. Just as there is a relation between gesture and form, we can suppose that there is also a connection between form and the sound created by knocking the bobbins. If the pattern of each stitch of the lace is related to a sequence of movements performed with the bobbin, each stitch can also be related to a specific rhythmic cadence. The pattern of each stitch would thus be related not only to the gestures that give rise to them, but also to the sound produced by how the bobbins are handled during their production.

Received: September 26, 2018

Approved: October 07, 2019

Translated by: Luiz Costa 


\section{Bibliography}

BIDET, Alexandra. 2007. "Le Corps, le rythme et l'esthetique sociale chez André Leroi-Gourhan”. Tecniques \& Culture, 48: 1-25.

BOAS, Franz. 1951. Primitive art. New York: Capitol Publishing Company.

BRUSSI, Júlia Dias Escobar. 2017. "Dos traços dos designers às linhas das rendeiras: os percursos de uma transformação". In: C. Sautchuk (org.), Técnicas e Transformação: perspectivas antropológicas. Rio de Janeiro: ABA Publicações. pp. 95-124.

. 2015. "Batendo bilros": rendeiras e rendas em Canaan (Trairi - CE). Tese de Doutorado, Programa de

Pós-Graduação em Antropologia Social da Universidade de Brasília - Brasília.

. 2009. Da "renda roubada" à renda exportada: a produção e a comercialização da renda de bilro em dois

contextos cearenses. Dissertação de Mestrado, Programa de Pós-Graduação em Antropologia Social da Universidade de Brasília - Brasília.

COUPAYE, Ludovic. 2017. "Cadeia operatória, transectos e teorias: algumas reflexões e sugestões sobre o percurso de um método clássico". In: C. Sautchuk (org.), Técnicas e Transformação: perspectivas antropológicas. Rio de Janeiro: ABA Publicações. pp. 475-494.

. 2009. "Ways of Enchanting: Chaînes Opératoire and Yam Cultivation in Nyamikum Village, Maprik, Papua New Guinea”. Journal of Material Culture, 14(4): 433-458.

CRESSWELL, Robert. 1996. Prométhée ou Pandore? Propos de technologie culturelle. Paris: Kimé.

FLEURY, Catherine Arruda Ellwanger. 2002. Renda de Bilro, Renda da Terra, Renda do Ceará: A Expressão

Artística de um Povo. São Paulo: Annablume.

INGOLD, Tim. 2002. "On Weaving a Basket". In: The Perception of the Environment: Essays on Livelihood, Dwelling \& Skill. London: Routledge. pp. 339-348.

. 2011. "Walking the Plank: Meditations on a Process of Skill". In: Being Alive: Essays on Movement, Knowledge and Description. London: Routledge. pp. 51-62.

2013a. "The Materials of Life". In: Making: Anthropology, Archaelogy, Art and Architecture. London:

Routledge. pp. 17-31.

2013b. "Telling by hand". In: Making: Anthropology, Archaelogy, Art and Architecture. London:

Routledge. pp. 109-124.

LEMONNIER, Pierre. 1992. Elements for an Anthropology of Technology. Ann Arbor, Michigan: Museum of

Anthropology, University of Michigan. (Anthropological papers, no 88)

. 1986. "The Study of Material Culture Today: Toward an Anthropology of Technical Systems. Journal

of Anthropological Archaelogy, 5: 147-186.

LEROI-GOURHAM, André. 1984 [1943]. Evolução e Técnicas I: O Homem e a Matéria. Lisboa: Edições 70. . 1985 [1945]. Evolução e Técnicas II: O Meio e as Técnicas. Lisboa: Edições 70.

1987 [1965]. O Gesto e a Palavra II: Memórias e Ritmos. Lisboa: Edições 70.

1990 [1964]. O Gesto e a Palavra I: Técnica e linguagem. Lisboa: Edições 70.

MAKOVICKY, Nicolette. 2006. Material Moralities: Craft, Network and Family Cosmology on Central Slovakia.

$\mathrm{PhD}$ Thesis, Departament of Anthropology of University College of London - London.

MAUSS, Marcel. 2003. "As Técnicas do Corpo”. In: Sociologia e Antropologia. São Paulo: Cosac Naify.

pp. 399-4022.

ROUX, Valentine; BRIL, Blandine. 2002. "Observation et Experimentation de Terrain: Des Collaborations

Fructueuses pour l'Analyse de l'Expertise Technique. Le Cas de la Taille de Pierre en Inde". In: V. Roux

\& B. Bril (eds.), Le Geste Technique: Réflexions Méthodologiques et Anthropologiques. Ramonville Saint-Agne:

Editions Erès. pp. 29-48. 
SCHLANGER, Nathan. 1991. "Le Fait Technique Total: La Raison Pratique et les Raisons de la Pratique dans l'Oeuvre de Marcel Mauss". Terrain, 16: 114-130.

. 2005. “The Chaîne Opératoire”. In: C. Renfrew \& P. Bahn (eds.), Archaeology: The Key Concepts. London: Routledge. pp. 18-23.

SENNET, Richard. 2009. O Artífice. Rio de Janeiro: Record.

SIGAUT, François. 2003a. “Technology”. In: T. Ingold (ed.), Companion Encyclopedia of Anthropology. London: Routledge. pp. 420-459.

SIGAUT, François. 2003b. “La Formule de Mauss”. Techniques \& Culture, 40. http://tc.revues.org/1538. Accessed on 06/06/2013.

VELTHEM, Lúcia Hussak van. 1998. A Pele de Tuluperê: Uma Etnografia dos trançados Wayana. Belém: Museu Paranaense Emílio Goeldi.

Júlia Dias Escobar Brussi

Federal University of Western Pará, Institute of Society Sciences,

Anthropology and Archeology Program, Santarém/PA, Brazil

https://orcid.org/0000-0003-3839-4132

Author's email: juliabrussi@gmail.com 